\title{
Erenumabo veiksmingumas ir saugumas: realios klinikinès praktikos rezultatų palyginimas su klinikinių tyrimų duomenimis
}

\section{A. Dapkutè K. Ryliškienè}

Vilniaus universiteto Medicinos fakultetas, Klinikines medicinos instituto Neurologijos ir neurochirurgijos klinika

\begin{abstract}
Santrauka. İvadas. Pirmasis Lietuvos rinkoje atsiradęs specifinis migrenos profilaktinis vaistas yra erenumabas, monokloninis antikūnas prieš su kalcitonino genu susijusio peptido receptorių. Jo efektyvumas ir saugumas anksčiau buvo įrodyti klinikiniais tyrimais, tačiau jau atsiranda publikacijų ir apie realius gydymo rezultatus.

Darbo tikslas. Palyginti erenumabo klinikinių tyrimų duomenis su publikuotais realios klinikinès praktikos veiksmingumo ir saugumo rezultatais.

Metodai. Literatūros paieškos kriterijus medicininèse ir klinikinių tyrimų duomenų bazèse atitiko 9 klinikiniai tyrimai ir 14 realios klinikinès patirties apžvalgų.

Rezultatai. Lyginant įvairius veiksmingumo kriterijus, erenumabas reikšmingai sumažino migrenos, galvos skausmo ir triptanų vartojimo dienų skaičių per mėnesị tiek klinikiniuose tyrimuose, tiek kasdienės klinikinės praktikos apžvalgose - pastarosiose rodikliai buvo reikšmingesni nei klinikiniuose tyrimuose. Realiomis sąlygomis buvo patvirtintas erenumabo veiksmingumas pacientams, sergantiems itin rezistentiška migrena. Dažniausias kasdienėje klinikinëje praktikoje stebimas nepageidaujamas reiškinys - vidurių užkietėjimas - ilgalaikiuose klinikiniuose tyrimuose fiksuotas retai. Tikètina, kad jis silpnejja erenumabą vartojant ilgesnį laiką ir priklauso nuo gyvenimo būdo bei mitybos ịpročių. Klinikiniuose tyrimuose įvykusių sunkių nepageidaujamų reiškinių ryšio su erenumabo vartojimu nebuvo nustatyta, kasdienės praktikos apžvalgose fiksuoti pavieniai sunkūs nepageidaujami reiškiniai, galimai sietini su erenumabo vartojimu. Erenumabo nutraukimo dažnis buvo tiesiogiai priklausomas nuo tyrimo trukmès ir dažnai buvo nulemtas asmeninio paciento sprendimo, nėštumo planavimo bei kitų, su vaisto saugumu nesusijusių, aplinkybių.

Išvados. Erenumabo veiksmingumas ir saugumas buvo patvirtinti tiek klinikinių tyrimų, tiek realios klinikinės praktikos duomenimis. Pastarojoje erenumabo veiksmingumas yra didesnis, nei nurodoma klinikiniuose tyrimuose, tačiau dažniau stebimi nepageidaujami reiškiniai, dažnesnis vaisto nutraukimas dẻl jų ir gydymo neefektyvumo.
\end{abstract}

Raktažodžiai: erenumabas, migrena, dažna epizodinė migrena, lètinė migrena, CGRP, monokloniniai antikūnai.

\section{IVADAS}

Migrena - tai pirminis galvos skausmas, dažnai siejamas su reikšminga socioekonomine našta ir sukeliama negalia.

\author{
Adresas: \\ Austëja Dapkutè \\ Vilniaus universiteto Medicinos fakulteto Klinikines medicinos \\ institutas, Neurologijos ir neurochirurgijos klinika \\ M. K. Čiurlionio g. 21, LT-03101 Vilnius \\ El.paštas austeja.dapkute@gmail.com
}

Skaičiuojama, kad apie $16 \%$ pasaulio populiacijos kenčia nuo šio sutrikimo [1]. Pagal 2017 m. atliktą Pasaulio ligu naštos studiją (angl. Global Burden of Disease Study), galvos skausmas buvo antra dažniausia liga tarp abiejų lyčiuc visose amžiaus grupèse, o pacientai, sergantys migrena, sudarė 43,37 \% turinčiųjų galvos skausmo sutrikimų. Migrenos paplitimas Lietuvoje $2017 \mathrm{~m}$. sudarè $22,99 \%$ visų ligų $[2,3]$.

Migrena yra multifaktorinė liga, kurios tipinio vienpusio, pulsuojančio skausmo patofiziologijai yra svarbi trišakio nervo aktyvacija. Nustatyta, kad nociceptinès trišakio

(C) Neurologijos seminarai, 2021. Open Access. This article is distributed under the terms of the Creative Commons Attribution 4.0 International License CC-BY 4.0 (http://creativecommons.org/licenses/by/4.0/), which permits unrestricted use, distribution, and reproduction in any medium, provided you give appropriate credit to the original author(s) and the source, provide a link to the Creative Commons license, and indicate if changes were made. 
1 lentelè. Analizuoti klinikiniai tyrimai

\begin{tabular}{|c|c|c|c|c|}
\hline Tyrimas & Fazè & Trukmė & Dalyvių skaičius & Dalyvių apibūdinimas \\
\hline NCT02066415 [12] & II & 12 sav. & 667 & Lètinès migrenos pacientai \\
\hline NCT0217486 [29] & II & 52 sav. atvira studija & 609 & $\begin{array}{l}\text { Lètinès migrenos pacientai, atviras } \\
\text { tyrimo Nr. NCT02066415 tęsinys }\end{array}$ \\
\hline NCT02630459 [46] & II & 24 sav. & 475 & $\begin{array}{l}\text { Epizodinès migrenos pacientai } \\
\text { japonai }\end{array}$ \\
\hline NCT01952574 [11, 15, 28] & II & 12 sav. (+5 m. atvira studija) & $483(383)$ & Epizodinès migrenos pacientai \\
\hline NCT02456740 [13] („STRIVE“) & III & 24 sav. (+28 sav. tęsinys) & 955 & Epizodinės migrenos pacientai \\
\hline NCT02483585 [14] („ARISE“) & III & 12 sav. (+28 sav. atvira studija) & 577 & Epizodinès migrenos pacientai \\
\hline NCT03096834 [30] („LIBERTY“) & III & 12 sav. & 246 & $\begin{array}{l}\text { Epizodinès migrenos pacientai, } \\
\text { nesėkmingai gydyti 2-4 profilak- } \\
\text { tiniais vaistais }\end{array}$ \\
\hline NCT03333109 [47] („EMPOwER“) & III & 12 sav. & 900 & Epizodinès migrenos pacientai \\
\hline NCT03812224 [48] & III & 24 sav. (+28 sav. atvira studija) & 261 & $\begin{array}{l}\text { Epizodinès migrenos pacientai } \\
\text { japonai }\end{array}$ \\
\hline
\end{tabular}

mazgo skaidulos išskiria su kalcitonino genu susijusį peptidą (angl. calcitonin gene-related peptide, CGRP) [4, 5]. Taip pat žinoma, kad intraveninė CGRP injekcija gali sukelti migrenos be auros priepuolį [6]. Šie ir panašūs tyrimai lèmé pasirinkti CGRP vienu pagrindinių vaistų nuo migrenos taikinių, o vaistų tyrimams pasukus biologinès terapijos linkme, monokloninių antikūnų taikiniais buvo pasirinktas CGRP ir jo receptorius. Vienintelis šiuo metu rinkoje esantis monokloninis antikūnas prieš CGRP receptorių yra vadinamas erenumabu (AMG-334, Aimovig) [7-9]. Šis vaistas buvo patvirtintas Europos vaistų agentūros $2018 \mathrm{~m}$. liepos mėnesi [8]. Lietuvos rinką jis pasieké $2018 \mathrm{~m}$. gruodị. Tyrimuose stebimas reikšmingas šio vaisto pranašumas prieš geriamuosius profilaktinius vaistus, ypač dèl jo vartojimo formos. Erenumabas, leidžiamas ị poodi, maksimalią koncentraciją pasiekia per 4-6 dienas. Pacientams rekomenduojamos injekcijos kas 4 savaites. Viena kasmėnesinė poodinè 70-140 mg erenumabo injekcija yra pakankama klinikiniam efektui pasiekti [8]. Atliktos klinikinès studijos su erenumabu, tarp jų ir tyrimai su pacientais, sergančiais kardiovaskulinėmis ligomis, stabilia krūtinès angina, įrodè vaisto saugumą [10]. Ilgalaikiam erenumabo saugumui ivertinti ir toliau atliekami tyrimai, kurių ilgiausias - atvira 5 metų trukmès studija, kurios rezultatai buvo paskelbti $2021 \mathrm{~m}$. sausio mènesi [11].

Erenumabas vis plačiau vartojamas kasdieneje praktikoje, todèl jau atsiranda publikacijų ir apie realius gydymo šiuo vaistu rezultatus. Šios apžvalgos tikslas - palyginti erenumabo klinikinių tyrimų duomenis su publikuotais realios klinikinès praktikos veiksmingumo bei saugumo rezultatais.

\section{METODAI}

Literatūros paieška buvo atlikta medicininėse duomenu bazėse (PubMed / Medline), naudojant raktažodžius „erenumab“, „real life“, iš pateiktų rezultatų rankomis atrinkus erenumabo naudojimo realioje klinikinejje praktikoje ap- žvalgas. Klinikinių tyrimų duomenys buvo gauti iš ClinicalTrials.gov duomenų bazès, naudojant ligos raktažodị „migraine“ ir vaisto raktažodi „erenumab“, atrinkus užbaigtus 2-3 fazès saugumo ir efektyvumo klinikinius tyrimus, kurių rezultatai jau yra publikuoti.

\section{Klinikiniai atsitiktinių imčių tyrimai}

Šios apžvalgos paieškos kriterijus atitiko 9 klinikiniai tyrimai: tarp jų 4 - II fazès ir 5 - III fazès (1 lentelè). Erenumabui registruoti Europos vaistų agentūrai (ang. European Medicines Agency, EMA) buvo pateikti keturių 2-3 fazès placebu kontroliuojamų dvigubai koduotų klinikinių tyrimų duomenys [12-15], kurių metu ši vaistą gavo 2537 pacientai, sergantys migrena [8]. Visų šių tyrimų metu erenumabas buvo skirtas daugiau nei 3800 pacientų [11]. Dvigubai koduotų, placebu kontroliuojamų tyrimų fazè truko vidutiniškai 12 savaičių, po jos seke atviri tyrimų tęsiniai 12 mènesių ir ilgiau trukusios studijos. Ilgiausios trukmès šiuo metu publikuoto atviro tyrimo duomenys $-5 \mathrm{~m}$. epizodinès migrenos studijos rezultatai. Šiame tyrime dalyvavo 383 pacientai [11].

Visuose klinikiniuose tyrimuose erenumabu buvo gydyta mažiausiai 1890 epizodinės migrenos pacientu ir 410 lẻtinès migrenos pacientų. Nors erenumabo veiksmingumas ir reti nepageidaujami reišskiniai buvo pripažinti ir ankstesniuose tyrimuose, ilgiausia $5 \mathbf{m}$. trukmès studija įrodo ilgalaikị erenumabo vartojimo saugumą ir veiksmingumą.

\section{Realios klinikinės patirties studijos}

Paieškos kriterijus atitiko 11 retrospektyvinių ir 3 prospektyviniai realios klinikinès patirties tyrimai (2 lentelè). Pirmieji 8 sav. erenumabo vartojimo rezultatai buvo publikuoti dar 2019 m. [16], vèliau, daugejjant patirties ir erenumabą vartojančių pacientų, duomenys plètėsi, atsirado 6-12 mèn. trukmès apžvalgos [17-23]. Buvo publikuota ir specifinių pacientų grupių apžvalgų: lètinès migrenos [17, 23], lètinès refraktorinès migrenos [24], pacientų, nesèk- 
2 lentelè. Analizuotos realios klinikinės patirties apžvalgos

\begin{tabular}{|c|c|c|c|}
\hline Apžvalgos autoriai & Trukmė & Pacientų skaičius & Tiriamoji populiacija \\
\hline Barbanti ir kt., 2019 [16] & 8 sav. & 78 & Italijos dažnos ir lètinès migrenos pacientai \\
\hline Ornello ir kt., 2020 [18] & 6 mèn. & 89 & $\begin{array}{l}\text { Italijos dažnos ir lètinès migrenos pacientai, nesėkmingai } \\
\text { gydyti } \geq 2 \text { profilaktiniais vaistais }\end{array}$ \\
\hline Ornello ir kt., 2020 [23] & 6 mèn. & 91 & Italijos lètinès migrenos pacientai \\
\hline Russo ir kt., 2020 [25] & 6 mèn. & 70 & $\begin{array}{l}\text { Italijos lètinės migrenos pacientai, nesėkmingai gydyti } \\
\geq 4 \text { profilaktiniais vaistais }\end{array}$ \\
\hline Ranieri ir kt., 2020 [20] & 12 mèn. & 30 & $\begin{array}{l}\text { Italijos epizodinės ir lėtinès migrenos pacientai, patiriantys } \\
>6 \text { MMD, nesékmingai gydyti } \geq 2 \text { profilaktiniais vaistais }\end{array}$ \\
\hline Valle ir kt., 2020 [19] & 40 sav. & 40 & $\begin{array}{l}\text { Italijos epizodinės ir lètinès migrenos pacientai, nesėkmingai } \\
\text { gydyti }>3 \text { profilaktiniais vaistais }\end{array}$ \\
\hline Raffaeli ir kt., 2020 [26] & 12 sav. & 139 & $\begin{array}{l}\text { Vokietijos lètinès migrenos pacientai, nesėkmingai gydyti } \\
5 \text { vaistais ir onabotulinotoksinu A }\end{array}$ \\
\hline Lambru ir kt., 2020 [24] & 6 mèn. & 162 & $\begin{array}{l}\text { Jungtinès Karalystès lètinès migrenos pacientai, nesėkmingai } \\
\text { gydyti } \geq 3 \text { profilaktiniais vaistais }\end{array}$ \\
\hline Kanaan ir kt., 2020 [27] & 8 mèn. & 241 & JAV epizodinès ir lètinès migrenos pacientai \\
\hline Matteo ir kt., 2020 [32] & 6 mèn. & 159 & $\begin{array}{l}\text { Italijos dažnos ir lètinès migrenos pacientai, nesėkmingai } \\
\text { gydyti } \geq 2 \text { profilaktiniais vaistais }\end{array}$ \\
\hline Cheng ir kt., 2020 [17] & 6 mèn. & 170 & Australijos lètinès migrenos pacientai \\
\hline Talbot ir kt., 2021 [22] & 9 mèn. & 98 & $\begin{array}{l}\text { Jungtinės Karalystės lètinès migrenos pacientai, nesèkmingai } \\
\text { gydyti onabotulinotoksinu A }\end{array}$ \\
\hline Barbanti ir kt., 2021 [41] & 12 sav. & 372 & Italijos dažnos ir lètinès migrenos pacientai \\
\hline Cainazzo ir kt., 2021 [21] & 12 mèn. & 81 & $\begin{array}{l}\text { Italijos lètinės migrenos pacientai, kuriems diagnozuotas ilgai } \\
\text { vartojamų vaistų sukeltas galvos skausmas }\end{array}$ \\
\hline
\end{tabular}

mingai gydytų daugiau nei 4 profilaktiniais vaistais [25], rezistentiškos onabotulinotoksinui A lètinès migrenos [22, 26], lètinès migrenos su ilgai vartojamų vaistų sukeltu galvos skausmu [21] populiacijose. Daugiausia pacientų itraukusios studijos buvo trijų Australijos galvos skausmo centrų retrospektyvinè lėtinės migrenos pacientų apžvalga [17] ir JAV retrospektyvinè studija [27].

Šiuo metu yra publikuoti duomenys apie mažiausiai 1700 pacientų, gydytų erenumabu realiomis klinikinèmis sąlygomis.

\section{REZULTATAI}

\section{Pacientų demografiniai rodikliai}

Klinikiniai tyrimai buvo atliekami gana siauroms populiacijoms (itraukti tik pacientai, sergantys epizodine migrena $(E M)[11,13,14,28]$, tik pacientai, sergantys lètine migrena (LM) [12, 29], tik pacientai, kuriems ankstesnis profilaktinis gydymas nebuvo sėkmingas [30], ar neitraukti pacientai, kuriems profilaktinis migrenos gydymas daugiau nei dviem vaistais nebuvo sèkmingas $[13,14])$. I ilgiausiai trunkantị klinikinic tyrimą buvo įtraukiami 18-60 m. asmenys, kuriems diagnozuota migrena $\geq 12$ mèn. iki tyrimo, patiriantys 4-14 migrenos dienų per mėnesic (MMD) [11]. Realioje klinikinèje patirtyje erenumabas buvo skiriamas atsižvelgiant ị mažiau griežtus kriterijus: šiam vaistui skirti nė vienoje aprašytoje populiacijoje nebuvo nustatyta viršutinè amžiaus riba, erenumabas buvo skiriamas tiek lètinès, tiek dažnos migrenos atvejais (esant $\geq 4$ galvos skausmo dienoms per mènesị). Griežtesni apribojimai buvo taikomi dẻl skirtingų erenumabo kompensavimo tvarkų ivairiose šalyse, pavyzdžiui, Vokietijoje erenumabas kompensuojamas tik pacientams, sergantiems LM, kuriems buvo neveiksmingi mažiausiai 5 profilaktiniai vaistai bei onabotulinotoksinas A, todèl šios šalies realios klinikinės patirties studija suteikia duomenis būtent apie šiuos kriterijus atitinkančius pacientus [26]. Didžiają dalị visų studijų sudarè pacientai, sergantys LM, dažnam jų buvo diagnozuotas ir ilgai vartojamų vaistų sukeltas galvos skausmas (ang. medication overuse headache, $\mathrm{MOH}$ ).

Realios klinikinės patirties apžvalgose galima rasti duomenų apie platesnes pacientų populiacijas nei klinikiniuose tyrimuose. Erenumabas dažniau buvo skirtas pacientams, sergantiems LM, su ilgai vartojamuc vaistų sukeltu galvos skausmu.

\section{Dozavimas}

Ilgiausiame klinikiniame tyrime visiems pacientams po $2 \mathrm{~m} .70 \mathrm{mg}$ erenumabo vartojimo dozè buvo padidinta iki $140 \mathrm{mg}$, to prireikè $65,3 \%$ visų tyrimą pradèjusių pacientų [11]. Atsitiktinių imčių dvigubai akluose klinikiniuose tyrimuose paciento gauta dozè buvo fiksuota. Realiomis klinikinėmis sąlygomis pradinė erenumabo dozė skyrèsi: Australijos apžvalgoje $140 \mathrm{mg}$ dozė pacientams, sergantiems LM, buvo pasirenkama dažniau [17]. Tikètina, kad pradinès $140 \mathrm{mg}$ dozès pasirinkimą pacientams, sergantiems LM, lėmė anksčiau publikuotos nuo dozès priklau- 
somą veiksmingumą nurodančios apžvalgos [31], taip pat tyrimuose pastebètas didesnis $140 \mathrm{mg}$ dozès veiksmingumas šiems pacientams [29]. Deja, kai kuriose šalyse pradinis didesnès erenumabo dozès skyrimas negalimas dèl nacionalinių vaisto kompensavimo ir skyrimo įstatymų [26]. Vokietijos, Jungtinės Karalystės, Italijos studijose visiems pacientams buvo skiriama pradinè $70 \mathrm{mg}$ dozè, nepaisant didelio anksčiau nesėkmingai vartotų profilaktinių vaistų skaičiaus [16, 24, 26]. Pacientams skyrus $70 \mathrm{mg}$ dozę, ji buvo didinama po vidutiniškai 2-3 mèn. nepasiekus $30 \%$ MMD [18, 25, 32] ar $50 \%$ MMD [24] sumažéjimo. Dozès padidinimo prireikè $26,4-74,1 \%$ pacientų $[18,20,22,23$, $25,26,32]$.

Didesnès pradinès dozès skyrimą pagrindžia didelis pacientų, sergančių LM, dažnis tiek klinikiniuose tyrimuose, tiek kasdienès klinikinės praktikos apžvalgose bei didesnis $140 \mathrm{mg}$ veiksmingumas šios grupès pacientams.

\section{Veiksmingumas}

Tiek klinikiniuose tyrimuose, tiek ir realios patirties apžvalgose pagrindiniais veiksmingumo rodikliais buvo pasirinktas MMD, galvos skausmo dienų per mėnesį, triptanų vartojimo dienų per mėnesic (dar įvardijamų specifinių vaistų vartojimo dienomis) sumažėjimas. Kitas svarbus rodiklis buvo procentinis MMD sumažèjimas: pacientus, patyrusius $\geq 50 \%$ skausmo ar migrenos dienų sumažèjimą laikant erenumabo poveiki patiriančiais (angl. responder), o patyrusius $\geq 75 \%$ sumažėjimą - reikšmingą poveiki patiriančiais (angl. super-responder) pacientais.

Klinikinėje lètinès migrenos studijoje stebėtas MMD sumažèjimas 6,6 d./mèn. [12], 52 sav. trunkančio šio tyrimo tęsinio rezultatuose matomas $8,5 \mathrm{~d}$./mèn. MMD sumažèjimas $70 \mathrm{mg}$ grupèje ir 10,5 d./mèn. - $140 \mathrm{mg}$ grupėje [33]. EM klinikiniuose tyrimuose MMD sumažèjo 2,9-3,7 d./mèn. [13, 14]. Ilgalaikiai rezultatai po 64 sav. nurodẻ MMD sumažèjimą 5 d./mèn. [28], o 5 m. studijoje nustatytas vidutiniškai 5,3 d./mèn. sumažèjimas pacientams, sergantiems EM [11]. Tiriant gydymui atsparią epizodinę migreną, nustatytas 1,8 d./mèn. MMD sumažèjimas vartojant 140 mg erenumabo dozę [30]. Tai būtų galima sieti su didesniu pirminiu MMD skaičiumi ir tikètinu panašiu procentiniu šių rodiklių sumažejjimu tarp pacientų, sergančių EM ir sergančių LM.

Realiomis klinikinėmis sąlygomis buvo stebėtas reikšmingas veiksmingumas: apibendrinant tyrimus, MMD sumažėjo 10,8-15 d./mėn., galvos skausmo dienų 9,2-13,5 d./mèn. pacientams, sergantiems dažna ir lètine migrena, per 6-12 mèn. [16-18, 22, 32]. Trumpesnès trukmès apžvalgose MMD sumažėjimas sudarè 3,8-4,9 d./mèn., skyrus $\geq 1$ dozę erenumabo [16, 26, 32]. Itin rezistentiškos migrenos tyrimuose pacientams, patyrusiems nesėkmingą gydymą penkiais ir daugiau profilaktinių vaistų, MMD per 5-8 sav. sumažèjo 4,9 d./mẻn., o galvos skausmo dienų - 5,3 d./mèn. [26].

Pacientai, patyrę MMD sumažėjimą $\geq 50 \%$, kasdienès klinikinès praktikos sąlygomis sudare $34,6 \%$ po pirmojo gydymo mėnesio [32], 46,5 \% pacientų, sergančių LM, po 6 mèn. gydymo erenumabu [17], o mažiau specifiškose populiacijose siekè 44,4-70 \% [16, 18-21, 25]. Didžiausias atsaką patyrusių pacientų dažnis nustatytas Italijos LM ir EM tyrime - 75,4 \% (30 \% jų patyrė $\geq 75 \%$ MMD sumažèjimą) [19], mažiausiai atsaką patyrusių pacientų nustatyta Jungtinès Karalystės atsparios kitam profilaktiniam gydymui LM studijoje - 38 \% [24]. Klinikiniuose tyrimuose buvo matomas panašus atsakas - juose $\geq 50 \%$ sumažejjimą pasiekè 40-41\% pacientų, sergančių LM, per 12-28 sav. ir 53,30-67,30\% - per 52 sav. [12, 33]. $\geq 50 \%$ pacientų, sergančių EM, atsakas klinikinėse studijose buvo $39,7-50 \%$ per $16-28$ sav. ir $65 \%$ - per 52 sav. [13, 14, 28], o $5 \mathrm{~m}$. trukmès studijoje pasiektas didžiausias - $71 \%$ atsaką patyrusių pacientų skaičius, iš kurių 47,1 \% MMD sumažejo $\geq 75 \%$, o 35,5 \% migrenos priepuoliai nesikartojo [11]. MMD sumažejjimas $\geq 75 \%$ EM 64 sav. studijoje buvo stebètas $42 \%$ pacientų [28]. Rezistentiškos migrenos tyrime, trukusiame 12 sav., $\geq 50 \%$ MMD sumažèjimas siekè $30 \%$ [30]. Labai panašus rezultatas buvo nustatytas ir kasdienėje klinikinejje praktikoje onabotulinotoksinui A rezistentiškos migrenos populiacijoje - 31,1 \% [26]. Kituose realios patirties tyrimuose pacientams, anksčiau nesėkmingai gydytiems keliais profilaktiniais vaistais, atsakas i erenumabą buvo panašesnis i bendros sergančiujų migrena populiacijos $(44,4-70 \%)[17,21,25]$. Vartojant erenumabą, sumažejus skausmo dienų skaičiui, kai kurių pacientų LM buvo perklasifikuota į EM - tokios konversijos dažnis buvo panašus ị atsaką patyrusių pacientų dažnị, priklausomai nuo tyrimo, ir siekè $45,4-70 \%$ pacientu (27\% po vienos dozès) [19, 23-25].

Klinikiniuose tyrimuose nustatytas ir specifinių vaistų vartojimo sumažèjimas 1,1-1,6 d./mèn. EM grupejje, jis priklausè nuo erenumabo dozès [13, 14]. $1 \mathrm{~m}$. trukmès studijos pratęsime vidutinis specifinių vaistų vartojimo dienų sumažėjimas pasiektas 2,4 d./mèn. [28], o $5 \mathrm{~m}$. trukmès studijoje siekè 4,4 d./mèn. [11]. Pacientams, sergantiems LM, jis buvo reikšmingesnis: 3,5-4,1 d./mèn. - 12 sav. tyrime ir 5 5,1 d./mèn. - 52 sav. tyrime [12, 33]. Realiomis sąlygomis pacientams, patyrusiems nesėkmingą gydymą $\geq 5$ profilaktiniais vaistais, nepaisant menko MMD sumažèjimo, triptanų vartojimo dienų pokytis buvo ryškus ir nuo 6,6 d./mėn. sumažèjo iki 1,4 d./mėn. [26]. Kituose realios patirties tyrimuose triptanų vartojimo dienų taip pat sumažèjo 4-5,2 d./mėn., nepriklausomai nuo tyrimo trukmès $[17,18,26]$. Viename dažnos ir lètinès migrenos kasdienès klinikinès praktikos tyrime pacientams specifinių vaistų vartojimo dienų skaičius sumažèjo 11,7 d./mėn. jau po pirmosios erenumabo injekcijos [32].

Reikšmingai sumažèjusius vaistų nuo skausmo vartojimo rodiklius galètų paaiškinti ne tik MMD sumažèjimas, bet ir susilpnėjęs migrenos priepuolio intensyvumas bei pagerèjęs priepuolių gydymo atsakas į nesteroidinius vaistus nuo uždegimo. Taip pat stebėtas kitų vaistų grupių vartojimo sumažejjimas: vidutiniškai $11,2-12,1 \%$ pacientu galejjo nutraukti kitą profilaktinị gydymą [18, 23], o nemaža dalis (25-54 \%) pacientų nebeatitiko $\mathrm{MOH}$ kriterijų [24]. İvairiuose tyrimuose buvo iškelta mintis, kad tinka- 
mas prevencinis gydymas gali padèti gydyti $\mathrm{MOH}$ - skaičiuojama, kad tarp visų pacientų, vartojančių erenumabą, MOH dažnis sumažėjo nuo 54 iki $25 \%$. İdomu, kad realiomis sąlygomis nebuvo nustatyta skirtumo tarp veiksmingumo MOH nesergančių ir sergančiųjų grupėse [24]. Taip pat pacientams, kuriems buvo diagnozuotas $\mathrm{MOH}$, erenumabas buvo veiksmingas tiek nutraukus simptomini priepuolio gydymą („detoksikuotoje grupeje“"), tiek ir be jo nutraukimo [21].

Lyginant ịvairius veiksmingumo kriterijus, erenumabas reikšmingai sumažino migrenos, galvos skausmo ir triptanų vartojimo dienų skaičių per mẻnesį tiek klinikiniuose tyrimuose, tiek kasdienès klinikinès praktikos apžvalgose - pastarosiose rodikliai ịprastai buvo dar reikšmingesni, nei klinikiniuose tyrimuose. Realiomis sąlygomis buvo patvirtintas erenumabo veiksmingumas pacientams, sergantiems itin rezistentiška migrena, ir jis taip pat buvo reikšmingesnis nei klinikiniuose tyrimuose. Dalis pacientų, sergančių LM, erenumabo gydymo metu galejjo būti perklasifikuoti i pacientus, sergančius EM, ir nebeturẻjo ilgai vartojamų vaistų sukelto galvos skausmo.

\section{Saugumas}

Klinikiniuose tyrimuose bent vieną nepageidaujamą reiškinị patyrė 14,86-26\% pacientų, sergančių EM ir LM [12-14, 33], dažniausi iš jų ( $\geq 3 \%)$ - injekcijos vietos skausmas, ūminès viršutinių kvėpavimo takų infekcijos, vidurių užkietėjimas [8]. Pacientams, sergantiems LM, dažniau pasireiškè injekcijos vietos skausmas, viršutiniu kvėpavimo takų infekcijos, pykinimas, nazofaringitas, vidurių užkietėjimas ir mėšlungis, visų jų dažnis nesiekė $5 \%$ [12]. EM tyrimuose dažniausi nepageidaujami reiškiniai buvo nazofaringitas ir viršutinių kvèpavimo takų infekcijos $[13,14,28]$. Sunkūs nepageidaujami reiškiniai fiksuoti $0-3,33 \%$ pacientų, tačiau ne dažniau nei placebo grupejje [12-14, 33], taip pat nestebèta širdies ir kraujagyslių ligụ atsiradimo ar gyvybinių funkcijų sutrikimų [10]. Nepageidaujamų reiškinių dažnis nepriklausė nuo tyrimo trukmės ir skiriamos erenumabo dozès. Ilgiausioje klinikinejje studijoje bent vieną nepageidaujamą reiškinị per $5 \mathrm{~m}$. patyrẻ $88,8 \%$ pacientų. Šis rodiklis nepriklausė nuo dozès. Dažniausiai pasireiškė nazofaringitas ir ūminès viršutinių kvėpavimo takų infekcijos. Tačiau iš placebu kontroliuojamų ankstesnių tyrimų taip pat buvo žinoma, kad šie reiškiniai erenumabą vartojantiems pacientams pasireiškia ne dažniau nei placebo grupeje. Tarp sunkių nepageidaujamų reiškinių (jie pasireiškẻ 12,8 \% pacientų) trims pacientams buvo nustatyti raiščių plyšimai, po du pacientus patyrė adaptacijos sutrikimą, sinkopes, gimdos lejomiomas, osteoartritą, apendicitą, giliụjų venų trombozę, krūties vėžì. Nenustatyta sunkaus nepageidaujamo poveikio sąsajų su erenumabo vartojimu [11].

Realios klinikinès patirties studijose Europos šalių populiacijose nepageidaujamus reiškinius patyrẻ 22,5-55,56\% pacientų, sunkių nepageidaujamų reiškinių šiuose tyrimuose nebuvo fiksuota [18, 20, 21, 24-26, 32].
Šie rodikliai JAV buvo daug didesni - bent vieną nepageidaujamą reiškini patyrè $70 \%$ pacientų. Taip pat buvo nustatyti pavieniai sunkūs nepageidaujami reiškiniai, tokie kaip plonųų žarnų obstrukcija (vienam pacientui). Dažniausiai pasireiškiantys nepageidaujami poveikiai buvo vidurių užkietejjimas (43\%), lokali injekcijos vietos reakcija (24\%), nuovargis (15\%), galvos skausmo sustiprèjimas (12\%) ir galvos svaigimas (11\%) [27]. Australijos populiacijoje taip pat fiksuoti pavieniai lètinių ligų (lètinio nuovargio sindromo, psoriatinio artrito, Krono ligos) paūmejjimo atvejai [17].

Trumpos trukmės klinikinių tyrimų vidurių užkietėjimo dažnis buvo 10,7 atvejo 100-ui pacientų metų $140 \mathrm{mg}$ grupejje ir 4,6 atvejo 100-ui pacientų metų $70 \mathrm{mg}$ grupejje [34]. STRIVE tyrime vidurių užkietẻjimas buvo dažnesnis $140 \mathrm{mg}$ grupejje ir jị siūlyta laikyti nuo dozès priklausomu nepageidaujamu reiškiniu [13]. Tačiau ilgos trukmès studijose skirtumo tarp dozių grupių nepastebèta ir bendras vidurių užkietejjimo dažnis stebėtas išskirtinai retai - tai buvo aiškinama šio simptomo išnykimu laikui bẻgant, stebètu ir placebu kontroliuojamuose tyrimuose [34, 35]. Per $5 \mathrm{~m}$. studiją nė vienas pacientas gydymo nenutraukẻ dèl vidurių užkietėjimo [11,35]. Kasdienėje klinikinėje praktikoje dažniausiai pranešta apie vidurių užkietejjimą, tačiau nepageidaujamų reiškinių dažnis labai skyrèsi, priklausomai nuo pacientų populiacijos. Australijos duomenimis, vidurių užkietėjimą patyrẻ 4,11\% pacientų, sergančių LM [17]. Europos populiacijose šis nepageidaujamas reiškinys fiksuotas $10-38,1 \%$ pacientų $[18,20,21,24-26$, 32]. JAV vidurių užkietėjimas pasireiškė $43 \%$ pacientų [27]. Šie skirtumai gali būti siejami su skirtingu žmonių gyvenimo būdu, vaistų vartojimu (pvz., priepuoliams vartojamų narkotinių analgetikų dažniu) ar mitybos ịpročiais, kurie skiriasi tarp JAV, Europos ir Australijos pacientu [36].

Nors klinikiniuose tyrimuose nebuvo pastebètas didesnis kardiovaskulinių nepageidaujamų reiškinių dažnis, lyginant su placebu [37], kasdienèje klinikinèje praktikoje keliuose tyrimuose pacientams buvo fiksuotas arterinio kraujo spaudimo (AKS) padidejjimas [24, 38] ir mikrovaskulinių ligų paūmėjimas [39]. Nustatyta, kad dažniausiai AKS padidejjimas pasireiškia per vieną savaitę, pradėjus vartoti erenumabą [38], ir grịžta ị pradinị lygị, nutraukus gydymą [24]. İ klinikinius tyrimus pacientai, turintys kardiovaskulinių rizikos veiksnių, įtraukiami nebuvo, tačiau tarp pacientų, kuriems AKS padidèjimas, pradėjus vartoti erenumabą, buvo nustatytas, $80,7 \%$ turèjo vieną ar daugiau širdies ar kraujagyslių ligų rizikos veiksnių (anksčiau diagnozuotą hipertenziją, dislipidemiją, cukrinị diabetą, nutukimą ar buvo vyresni nei $65 \mathrm{~m}$.) [38]. Tiriant CGRP antagonistų poveikị Raynaud fenomeną patiriantiems pacientams, 5,3\% tiriamujų pasireiškė įvairaus masto mikrovaskulinės komplikacijos: paūmėjęs Raynaud fenomenas, paūmèjusios veido telangiektazès, rankų pirštų išopejjimai, pirštų akroosteolizė ir gangreninė nekrozė, lèmusi dviejų pirštų amputaciją. 5 iš $9(55,55 \%)$ pacientų, patyrusių šias komplikacijas, vartojo erenumabą [39]. 
Dažniausias kasdienèje klinikinèje praktikoje stebimas nepageidaujamas reiškinys - vidurių užkietẻjimas - ilgalaikiuose klinikiniuose tyrimuose fiksuojamas retai, todèl manoma, kad jis silpnèja, erenumabą vartojant ilgesnị laiką, ir priklauso nuo gyvenimo būdo bei mitybos ịpročių. AKS padidẻjimas, stebimas realioje klinikinëje praktikoje, yra praeinantis (tranzitorinis) ir dažniausiai pasireiškia pacientams, turintiems kardiovaskulinių rizikos veiksnių. Klinikiniuose tyrimuose įvykusių sunkių nepageidaujamų reiškinių ryšio su erenumabo vartojimu nebuvo nustatyta, kasdienès praktikos apžvalgose fiksuoti pavieniai sunkūs nepageidaujami reiškiniai, galimai sietini su erenumabo vartojimu.

\section{Gydymo nutraukimas}

Nutraukimo dažnis trumpos trukmès klinikiniuose tyrimuose buvo 5,5-7,1\%, o ilgos trukmès - 17,6 \% [34]. Iš $5 \mathrm{~m}$. trukusio klinikinio tyrimo pasitraukè 43,86\% dalyvių, tačiau dèl nepageidaujamų reiškinių gydymą nutraukẻ tik 4,7 \% pacientų - dažniausiai jis buvo nutrauktas paciento pageidavimu. Dažniausi nepageidaujami reiškiniai, lèmę gydymo nutraukimą, buvo odos bẻrimas ir depresija $[11,35]$. Kituose klinikiniuose tyrimuose nutraukimo dažnis dèl nepageidaujamų reiškinių buvo: 1-2,5 \% [12-15] trumpos trukmès tyrimuose ir 2,2-2,4 \% - ilgos trukmès tyrimuose [34]. Jau anksčiau apžvalgose buvo pastebèta, kad erenumabo nutraukimo dažnis buvo daug mažesnis už geriamụjų vaistų nuo migrenos nutraukimo dažnị [13].

Realios klinikinès praktikos sąlygomis pacientai gydymą nutraukẻ dẻl menko veiksmingumo $(6,2-14,6 \%)$, néštumo, lètinių ligų paūmèjimo [17-19, 21, 32]. JAV stebètas ir nutraukimas dèl per didelès vaisto kainos [27]. Didžiausias nutraukimo dèl menko veiksmingumo dažnis (18\%) stebètas tarp pacientų su lètine, onabotulinotoksinui A rezistentiška migrena [22]. Didžiausias nutraukimo dẻl nepageidaujamų reiškinių dažnis stebẻtas JAV ir Jungtinès Karalystès populiacijose - $12 \%$ [24, 27] (JAV ši priežastis sudarė $34,9 \%$ visų pacientų, nutraukusių gydymą). Taip pat dalis JAV pacientų, kuriems buvo skirtas gydymas erenumabu, jo nepradèjo dèl didelès vaisto kainos [27]. Kituose tyrimuose stebètas 0-6,2 \% erenumabo nutraukimas dèl nepageidaujamų reiškinių [18, 20-22, 26].

Erenumabo nutraukimo dažnis buvo tiesiogiai priklausomas nuo tyrimo trukmès ir dažnai buvo nulemtas asmeninio paciento sprendimo, néštumo planavimo bei kitų, su vaisto saugumu nesusijusių, aplinkybių.

\section{Kiti realios klinikinės praktikos aspektai}

Tinkamų pacientų atranka. Tyrimuose pastebėta, kad dalis pacientų, gydomų erenumabu, nepajunta jokio pagerejimo - Vokietijos realios patirties studijoje tokie pacientai sudarè $24,4 \%$ visų tiriamųų. Paminètina, kad šioje studijoje visi pacientai sirgo LM ir buvo neefektyviai gydyti bent 5 kitais profilaktiniais vaistais bei onabotulinotoksinu A [26]. Kyla klausimas, ar įmanoma prognozuoti erenu- mabo veiksmingumą pagal tam tikrus paciento ir jo ligos požymius. Triptanai ir erenumabas veikia blokuodami CGRP signalinị kelią, taigi manoma, kad erenumabas gali būti veiksmingesnis pacientams, patiriantiems gerą atsaką ị migrenos priepuolių gydymą triptanais. Realios klinikinès patirties tyrimuose šis ryšys buvo patvirtintas - nustatyta, kad pacientai, kurie patyrè atsaką i bent vieną iš triptanų, turi didesnę tikimybę sulaukti teigiamo efekto, gydant erenumabu [16, 40, 41], taip pat pastebètas didesnis erenumabo veiksmingumas pacientams, patiriantiems alodiniją [16], besiskundžiantiems vienpuse skausmo lokalizacija, didesniu pirminiu migrenos dienų per mėnesị skaičiumi, dopaminerginiais simptomais (žiovulys, mieguistumas, pykinimas, vėmimas) [41]. Mažesnis erenumabo veiksmingumas stebėtas pacientams, turintiems gretutinių psichiatrinių sutrikimų, neefektyviai gydytiems didesniu skaičiumi kitų profilaktinių vaistų [41] ir turintiems ilgesnę migrenos trukmę [25].

Optimali gydymo trukmė. Dažniausiai kasdienėje klinikinejje praktikoje stebima erenumabo gydymo trukmè - 6-12 mèn., tačiau tikslių šio vaisto skyrimo trukmès gairių kol kas nèra. Dažniausiai remiamasi empiriniais stebẻjimais ir nedidele ilgesnių tyrimų patirtimi. Remiantis kitų lètinių, priepuoline eiga pasižyminčių neurologinių ir psichiatrinių sutrikimų, tokių kaip epilepsija ar panikos priepuoliai, sèkmingo profilaktinio gydymo pavyzdžiais, svarstoma, kad, siekiant išlaikyti aukštą erenumabo efektyvumą, gydymą reikètų tęsti ilgiau [16]. Didžiausias migrenos dienu per mėnesị skaičiaus sumažèjimas buvo pasiektas $5 \mathrm{~m}$. trukmės klinikinëje EM studijoje [11]. Tai galètų nurodyti, kad erenumabo veiksmingumas didèja ir tiesiogiai priklauso nuo gydymo trukmès. Nespecifinès migrenos profilaktikos minimali vartojimo trukmè yra panaši i erenumabo, siekia 6-12 mèn., tačiau dažnai yra apribojama dažnų nepageidaujamų reiškinių, menko efektyvumo $[13,42]$. Ilgiausio iki šiol atlikto erenumabo klinikinio tyrimo duomenimis, $62 \%$ pacientų tyrime gydymą tęsė $3 \mathrm{~m}$. [35], o 39,7 \% vaistą vartojo visą tyrimo laiką [11]. Tai ịrodo vaisto efektyvumą, naudos pranašumą prieš nepageidaujamus reiškinius ir bendrą pacientų pasitenkinimą gydymu. Erenumabo veiksmingumo po nutraukimo tyrime taip pat buvo stebimas būklès pablogejjimas erenumabą nutraukus po $1 \mathrm{~m}$. vartojimo (poveikis išliko $56 \%$ iš visu ji patyrusių pacientų, $31 \%$ turèjo vèl pradèti gydymą) [43]. Remiantis šiais duomenimis, galima spèti, kad erenumabo veiksmingumo užtikrinimas galimas tik jị vartojant nuolat.

Erenumabo ir onabotulinotoksino A sudètinè terapija. Vartodami erenumabą, dalis pacientų galèjo sumažinti ar visiškai nutraukti kitą profilaktinį gydymą [18, 23]. Visgi, didelè dalis pacientų ir vartodami erenumabą neišvengia kitų profilaktiniu vaistų poreikio. Svarstoma, ar erenumabas galètų turèti sinergistinị poveikị su kitais profilaktiniais vaistais nuo migrenos. Onabotulinotoksinas A yra vaistas, klinikiniais tyrimais patvirtintas lètinei migrenai gydyti, tad buvo pasirinktas įvertinti tokią hipotezę studijose, pacientams skiriant erenumabą (ar kitus monokloninius antikūnus prieš CGRP) kartu su onabotulinotoksinu A, buvo pastebètas statistiškai reikšmingas migrenos 
dienų per mėnesị skaičiaus ir galvos skausmo intensyvumo sumažejimas, palyginus su pacientais, gydomais tik onabotulinotoksinu A [44, 45]. Taigi pacientams, kuriems gydymas tik pastaruoju vaistu ar erenumabu nèra pakankamai efektyvus, išlieka didesnè teigiamo poveikio tikimybė kombinuojant šiuos gydymo metodus.

\section{IŠVADOS}

Erenumabo veiksmingumas ir saugumas buvo patvirtinti tiek klinikinių tyrimų, tiek realios klinikinès praktikos duomenimis pacientams, sergantiems epizodine, lètine ir kitiems profilaktiniams vaistams atsparia lètine migrena. Realioje klinikineje praktikoje erenumabo veiksmingumas yra didesnis, nei nurodoma klinikiniuose tyrimuose, tačiau dažniau stebimi nepageidaujami reiškiniai, dažnesnis vaisto nutraukimas dẻl jų ir gydymo neefektyvumo.

\section{Literatūra}

1. Noseda R, Burstein R. Migraine pathophysiology: anatomy of the trigeminovascular pathway and associated neurological symptoms, cortical spreading depression, sensitization, and modulation of pain. Pain 2013; 154(Suppl 1): S44-53. https://doi.org/10.1016/j.pain.2013.07.021

2. James SL, Abate D, Abate KH, et al. Global, regional, and national incidence, prevalence, and years lived with disability for 354 diseases and injuries for 195 countries and territories, 1990-2017: a systematic analysis for the Global Burden of Disease Study 2017. Lancet 2018; 392: 1789-858. https://doi.org/10.1016/S0140-6736(18)32279-7

3. Institute for Health Metrics and Evaluation (IHME). GBD Compare Data Visualization [cited 2020 Mar 24]. Available from: http://vizhub.healthdata.org/gbd-compare

4. Olesen J, Burstein R, Ashina M, et al. Origin of pain in migraine: evidence for peripheral sensitisation. Lancet Neurol 2009; 8: 679-90. https://doi.org/10.1016/S14744422(09)70090-0

5. Goadsby PJ, Edvinsson L, Ekman R. Vasoactive peptide release in the extracerebral circulation of humans during migraine headache. Ann Neurol 1990; 28: 183-7. https://doi.org/10.1002/ana.410280213

6. Lassen LH, Haderslev PA, Jacobsen VB, et al. CGRP may play a causative role in migraine. Cephalalgia 2002; 22: 54-61. https://doi.org/10.1046/j.1468-2982.2002. 00310.x

7. Tringali G, Navarra P. Anti-CGRP and anti-CGRP receptor monoclonal antibodies as antimigraine agents. Potential differences in safety profile postulated on a pathophysiological basis. Peptides 2019; 116: 16-21. https://doi.org/10.1016/ j.peptides.2019.04.012

8. European Medicines Agency. Aimovig [cited 2020 Apr 15]. Available from: https://www.ema.europa.eu/en/medicines/ human/EPAR/aimovig

9. U. S. Food and Drug Administration. FDA-Approved Drugs [cited 2020 Apr 8]. Available from: https://www.accessdata. fda.gov/scripts/cder/daf/index.cfm

10. Depre C, Antalik L, Starling A, et al. A randomized, doubleblind, placebo-controlled study to evaluate the effect of erenumab on exercise time during a treadmill test in patients with stable angina. Headache 2018; 58: 715-23. https://doi.org/10.1111/head.13316

11. Ashina M, Goadsby PJ, Reuter U, et al. Long-term efficacy and safety of erenumab in migraine prevention: results from a 5-year, open-label treatment phase of a randomized clinical trial. Eur J Neurol 2021; 28: 1716-25. https://doi.org/ 10.1111/ene. 14715

12. Tepper S, Ashina M, Reuter U, et al. Safety and efficacy of erenumab for preventive treatment of chronic migraine: a randomised, double-blind, placebo-controlled phase 2 trial. Lancet Neurol 2017; 16: 425-34. https://doi.org/10.1016/ S1474-4422(17)30083-2

13. Goadsby PJ, Reuter U, Hallström Y, et al. A controlled trial of erenumab for episodic migraine. N Engl J Med 2017; 377: 2123-32. https://doi.org/10.1056/NEJMoa1705848

14. Dodick DW, Ashina M, Brandes JL, et al. ARISE: a phase 3 randomized trial of erenumab for episodic migraine. Cephalalgia 2018; 38: 1026-37. https://doi.org/10.1177/ 0333102418759786

15. Sun H, DodickDW, Silberstein S, et al. Safety and efficacy of AMG 334 for prevention of episodic migraine: a randomised, double-blind, placebo-controlled, phase 2 trial. Lancet Neurol 2016; 15: 382-90. https://doi.org/10.1016/S14744422(16)00019-3

16. Barbanti P, Aurilia C, Egeo G, et al. Erenumab: from scientific evidence to clinical practice - the first Italian real-life data. Neurol Sci 2019; 40: 177-9. https://doi.org/10.1007/ s10072-019-03839-x

17. Cheng S, Jenkins B, Limberg N, et al. Erenumab in chronic migraine: an Australian experience. Headache 2020; 60: 2555-62. https://doi.org/10.1111/head.13968

18. Ornello R, Casalena A, Frattale I, et al. Real-life data on the efficacy and safety of erenumab in the Abruzzo region, central Italy. J Headache Pain 2020; 21: 32. https://doi.org/ 10.1186/s10194-020-01102-9

19. Valle ED, Di Falco M, Mancioli A, et al. Efficacy and safety of erenumab in the real-life setting of S. Antonio Abate Hospital's Headache Center (Gallarate). Neurol Sci 2020; 41: 465. https://doi.org/10.1007/s10072-020-04752-4

20. Ranieri A, Alfieri G, Napolitano M, et al. One year experience with erenumab: real-life data in 30 consecutive patients. Neurol Sci 2020; 41: 505-6. https://doi.org/10.1007/s10072020-04677-y

21. Cainazzo MM, Baraldi C, Ferrari A, et al. Erenumab for the preventive treatment of chronic migraine complicated with medication overuse headache: an observational, retrospective, 12-month real-life study. Neurol Sci 2021; 42(10): 4193-202. https://doi.org/10.1007/s10072-02105105-5

22. Talbot J, Stuckey R, Crawford L, et al. Improvements in pain, medication use and quality of life in onabotulinumtoxinA-resistant chronic migraine patients following erenumab treatment - real world outcomes. J Headache Pain 2021; 22: 5. https://doi.org/10.1186/s10194-020-01214-2

23. Ornello R, Casalena A, Frattale I, et al. Conversion from chronic to episodic migraine in patients treated with erenumab: real-life data from an Italian region. J Headache Pain 2020; 21: 102. https://doi.org/10.1186/s10194-02001171-w

24. Lambru G, Hill B, Murphy M, et al. A prospective real-world analysis of erenumab in refractory chronic migraine. J Headache Pain 2020; 21: 61. https://doi.org/10.1186/s10194020-01127-0 
25. Russo A, Silvestro M, Scotto di Clemente F, et al. Multidimensional assessment of the effects of erenumab in chronic migraine patients with previous unsuccessful preventive treatments: a comprehensive real-world experience. J Headache Pain 2020; 21: 69. https://doi.org/10.1186/s10194020-01143-0

26. Raffaelli B, Kalantzis R, Mecklenburg J, et al. Erenumab in chronic migraine patients who previously failed five first-line oral prophylactics and onabotulinumtoxinA: a dual-center retrospective observational study. Front Neurol 2020; 11: 417. https://doi.org/10.3389/fneur.2020.00417

27. Kanaan S, Hettie G, Loder E, et al. Real-world effectiveness and tolerability of erenumab: a retrospective cohort study. Cephalalgia 2020; 40: 1511-22. https://doi.org/10.1177/ 0333102420946725

28. Ashina M, Dodick D, Goadsby PJ, et al. Erenumab (AMG 334) in episodic migraine: interim analysis of an ongoing open-label study. Neurology 2017; 89: 1237-43. https://doi.org/10.1212/WNL.0000000000004391

29. Tepper SJ, Ashina M, Reuter U, et al. Assessment of the long-term safety and efficacy of erenumab during open-label treatment of patients with chronic migraine (P1.10-016). Neurology 2019; 92(Suppl 15): P1.10-016.

30. Reuter U, Goadsby PJ, Lanteri-Minet M, et al. Efficacy and tolerability of erenumab in patients with episodic migraine in whom two-to-four previous preventive treatments were unsuccessful: a randomised, double-blind, placebo-controlled, phase 3b study. Lancet 2018; 392: 2280-7. https://doi.org/ 10.1016/S0140-6736(18)32534-0

31. Ornello R, Tiseo C, Frattale I, et al. The appropriate dosing of erenumab for migraine prevention after multiple preventive treatment failures: a critical appraisal. J Headache Pain 2019; 20: 99. https://doi.org/10.1186/s10194-019-1054-4

32. Matteo E, Favoni V, Pascazio A, et al. Erenumab in 159 high frequency and chronic migraine patients: real-life results from the Bologna Headache Center. Neurol Sci 2020; 41: 483-4. https://doi.org/10.1007/s10072-020-04667-0

33. Tepper SJ, Ashina M, Reuter U, et al. Long-term safety and efficacy of erenumab in patients with chronic migraine: results from a 52-week, open-label extension study. Cephalalgia 2020; 40(6): 543-53. https://doi.org/10.1177/ 0333102420912726

34. Ashina M, Kudrow D, Reuter U, et al. Long-term tolerability and nonvascular safety of erenumab, a novel calcitonin gene-related peptide receptor antagonist for prevention of migraine: a pooled analysis of four placebo-controlled trials with long-term extensions. Cephalalgia 2019; 39: 1798-808. https://doi.org/10.1177/0333102419888222

35. Ashina M, Goadsby PJ, Reuter U, et al. Long-term safety and tolerability of erenumab: three-plus year results from a fiveyear open-label extension study in episodic migraine. Cephalalgia 2019; 39: 1455-64. https://doi.org/10.1177/ 0333102419854082

36. Raffaelli B, Neeb L, Reuter U. Monoclonal antibodies for the prevention of migraine. Expert Opin Biol Ther 2019; 19: 1307-17. https://doi.org/10.1080/14712598.2019. 1671350

37. Kudrow D, Pascual J, Winner PK, et al. Vascular safety of erenumab for migraine prevention. Neurology 2020; 94: e497-510. https://doi.org/10.1212/WNL. 0000000000008743

38. Saely S, Croteau D, Jawidzik L, et al. Hypertension: a new safety risk for patients treated with erenumab. Headache 2021; 61: 202-8. https://doi.org/10.1111/head.14051
39. Breen ID, Brumfiel CM, Patel MH, et al. Evaluation of the safety of calcitonin gene-related peptide antagonists for migraine treatment among adults with Raynaud phenomenon. JAMA Netw Open 2021; 4(4): e217934. https://doi.org/ 10.1001/jamanetworkopen.2021.7934

40. Frattale I, Caponnetto V, Casalena A, et al. Association between response to triptans and response to erenumab: reallife data. J Headache Pain 2021; 22: 1. https://doi.org/ 10.1186/s10194-020-01213-3

41. Barbanti P, Aurilia C, Egeo G, et al. Erenumab in the prevention of high-frequency episodic and chronic migraine: Erenumab in Real Life in Italy (EARLY), the first Italian multicenter, prospective real-life study. Headache 2021; 61: 363-72. https://doi.org/10.1111/head.14032

42. Hepp Z, Dodick DW, Varon SF, et al. Persistence and switching patterns of oral migraine prophylactic medications among patients with chronic migraine: a retrospective claims analysis. Cephalalgia 2017; 37: 470-85. https://doi.org/ 10.1177/0333102416678382

43. De Matteis E, Affaitati G, Frattale I, et al. Early outcomes of migraine after erenumab discontinuation: data from a real-life setting. Neurol Sci 2021; 42(8): 3297-303. https://doi.org/10.1007/s10072-020-05022-z

44. Cohen F, Armand C, Lipton RB, et al. Efficacy and tolerability of calcitonin gene-related peptide targeted monoclonal antibody medications as add-on therapy to onabotulinumtoxinA in patients with chronic migraine. Pain Med 2021; 22(8): 1857-63. https://doi.org/10.1093/pm/ pnab093

45. Armanious M, Khalil N, Lu Y, et al. Erenumab and onabotulinumtoxinA combination therapy for the prevention of intractable chronic migraine without aura: a retrospective analysis. J Pain Palliat Care Pharmacother 2021; 35(1): 1-6. https://doi.org/10.1080/15360288.2020.1829249

46. Sakai F, Takeshima T, Tatsuoka $\mathrm{Y}$, et al. A randomized phase 2 study of erenumab for the prevention of episodic migraine in Japanese adults. Headache 2019; 59: 1731-42. https://doi.org/10.1111/head.13652

47. Novartis Pharmaceuticals. A 12-week double-blind, randomized, multi-center study comparing the efficacy and safety of once monthly subcutaneous AMG 334 against placebo in adult episodic migraine patients (EMPOwER). Report No.: NCT03333109 [cited 2021 Apr 21]. Available from: https://clinicaltrials.gov/ct2/show/results/ NCT03333109

48. Amgen. A phase 3 Japanese randomized, double-blind, placebo-controlled study to evaluate the efficacy and safety of erenumab in migraine prevention. Report No.: NCT03812224 [cited 2021 Apr 21]. Available from: https://clinicaltrials.gov/ct2/show/results/NCT03812224

\section{A. Dapkutė, K. Ryliškienė \\ ERENUMAB EFFECTIVENESS AND SAFETY: COMPARISON OF REAL-LIFE DATA AND CLINICAL TRIAL RESULTS}

\section{Summary}

Background. Erenumab was the first preventive medication targeted to the pathogenesis of migraine to reach Lithuanian market. Previously, evidence of the safety and efficacy of erenumab was supported only by clinical study results, but more recently, real-life data started to appear. The aim of this review is to com- 
pare erenumab clinical trial results with already published real-life data in terms of its effectiveness and safety.

Methods. Data search was performed in medical literature and international clinical trial databases. 9 clinical trials and 14 real-life data publications were included in this review.

Results. Erenumab significantly reduced monthly migraine, headache, and triptan usage days per month both in clinical trials and in real-life data reports. In real-life settings erenumab effectiveness proved to be even greater than in clinical trials. It was also confirmed that erenumab is an effective treatment for highly resistant chronic migraine. However, adverse event frequency was higher in real-life settings, and the most often observed adverse event was constipation. During long-term trials it was less prominent, therefore, it is hypothesised that constipation reduces with time and is highly dependent on lifestyle and dietary habits. No severe adverse events related to erenumab usage were ob- served in clinical trials, and in real-life settings, severe adverse events that might be related to erenumab usage were extremely rare. Treatment withdrawal was higher in real-life data reports and it was directly related to study duration. It was often caused by personal patient decision, pregnancy planning, and other non-safety related circumstances.

Conclusions. Erenumab effectiveness and safety was proved both by clinical trial results and by real-life data. The latter demonstrated greater erenumab effectiveness in real-life settings, as well as higher adverse event frequency and higher treatment withdrawal rate due to adverse events and unsatisfactory results.

Keywords: erenumab, migraine, frequent episodic migraine, chronic migraine, CGRP, monoclonal antibodies.

Gauta:

Priimta spaudai:

20210531
20210610 